Research article

\title{
THE ELECTROPHORETIC PATTERN OF SERUM PROTEINS IN DAIRY COWS WITH INFLAMMATORY DISEASES
}

\author{
TÓTHOVÁ Csilla*, MUDROŇ Pavol, NAGY Oskar
}

Clinic for Ruminants, University of Veterinary Medicine and Pharmacy, Košice, Slovak Republic

(Received 15 August 2016, Accepted 13 February 2017)

\begin{abstract}
The objective of the study was to evaluate the electrophoretic pattern of serum proteins in dairy cows suffering from various inflammatory diseases, and to study the influence of these diseases on the concentrations of protein fractions. Fourty dairy cows with clinical signs of various inflammatory diseases were used in the study, including cows with post-partum metritis $(\mathrm{n}=10)$, mastitis $(\mathrm{n}=7)$, and hoof diseases $(\mathrm{n}=23)$. The cows were of a black pied Holstein-Friesian breed, Slovak spotted breed and their crossbreeds at the age of 3.5 to 8 years. Fourteen clinically healthy dairy cows were taken as the control group. The cows were blood sampled for the determination of total serum proteins and serum protein fractions. The protein fractions were divided into albumin, $\alpha_{1}^{-}, \alpha_{2}, \beta_{1}^{-}, \beta_{2}$, and $\gamma$-globulins. In cows with post-partum metritis we found significantly lower concentrations of albumin $(\mathrm{P}<0.001)$ and significantly higher values of $\alpha_{1}$-globulins $(\mathrm{P}<0.01)$ compared with healthy animals. Significantly higher concentrations of $\beta_{1}$-globulins were observed in cows with mastitis $(\mathrm{P}<0.001)$, while the $\gamma$-globulin fraction was non-significantly higher. In cows with hoof diseases we recorded significantly lower values of albumin $(\mathrm{P}<0.001)$, significantly higher concentrations of $\alpha_{1}$ - and $\beta_{1}$-globulins $(\mathrm{P}<0.001)$, and non-significantly higher $\beta_{2}$ - and $\gamma$-globulins. Moreover, in the electrophoretic pattern of serum proteins we found $\beta-\gamma$ bridging in thirteen cows with hoof diseases. Presented data suggest marked influence of inflammatory diseases on the concentrations of serum protein fractions in dairy cows. However, further investigations are needed to establish the diagnostic utility of serum protein electrophoresis in bovine clinical practice in relation to inflammatory diseases.
\end{abstract}

Key words: dairy cows, electrophoresis, lameness, mastitis, metritis, protein fractions.

\section{INTRODUCTION}

Electrophoresis is currently regarded as the standard technique for fractionation of serum proteins in clinical biochemistry and for detecting changes in the protein fractions [1]. It can provide important information for the diagnosis, prognosis, monitoring of various diseases, and to determine appropriate treatment [2]. The separation and identification of different protein fractions may help to understand the pathological

\footnotetext{
*Corresponding author: e-mail: tothova@uvm.sk
} 
changes associated with different disease conditions [3]. Because dysproteinemia is associated with several diseases, it is important to determine the differences in protein electrophoretograms between healthy animals and cases affected by various diseases. Serum protein electrophoresis has been intensively studied in small animals medicine $[4,5]$. However, published reports about the changes in serum protein fractions in farm animals, including cows affected by some frequent diseases as mastitis, metritis and hoof diseases are very limited. These belong to serious production diseases in dairy livestock, which may cause decreases in milk production and fertility, and increased risk of culling [6,7]. These diseases may be associated with systemic acute phase response and increased concentrations of acute phase proteins [8,9]. Although it is known that inflammatory processes may be associated with changes in the serum protein pattern, there is a lack of information on the possible effect of inflammatory production diseases on the electrophoretic profile of serum proteins. Therefore, the aim of this study was to determine and describe the serum protein electrophoretic pattern in dairy cows affected by inflammatory diseases, including mastitis, metritis and hoof diseases, and to evaluate the changes in protein fractions compared with clinically healthy animals.

\section{MATERIAL AND METHODS}

Into the evaluation we included 40 multiparous dairy cows with various inflammatory diseases submitted to the Clinic for Ruminants of the University of Veterinary Medicine and Pharmacy in Košice, Slovak Republic. The cows were of a black pied Holstein-Friesian breed, Slovak spotted breed and their crossbreeds at the age of 3.5 to 8 years, and in different stages of lactation. They came from three conventional dairy farms with similar feeding and management regimes. The animals were fed diets according to their actual milk production and gestation period. Water was available freely in automatic drinking troughs. The cows were milked twice a day. After arrival to the clinic, the cows were clinically examined according to standard examination procedures. Clinical examinations included the assessment of the overall health status of the animals (food intake, behavior), inspection and recording of body temperature, respiratory and pulse rates, and a detailed evaluation of the organ systems [10]. According to the clinical findings, the cows were divided into the following groups:

- cows with post-partum clinical metritis $(n=10)$ - with abnormal enlarged uterus, obvious red-brownish watery or viscous off-white purulent uterine discharge, accompanied by foul odor; they showed no signs of systemic illness within 21 days after parturition,

- cows with clinical mastitis $(n=7)$ - the mastitic cows showed clinical signs such as redness, hardness, swelling and pain in the udder, or changes in milk color, and presence of clots in the milk;

- cows with hoof diseases $(n=23)$ - pododermatitis, laminitis, sole ulcer, and digital dermatitis of various degree were found in these cows during the diagnostics of the cause of lameness. 
Fourteen clinically healthy dairy cows without any signs of diseases and in good general condition were taken as a control group.

After initial clinical examination and establishment of the diagnosis, the evaluated cows were blood sampled for the determination of the concentrations of total serum proteins and separation of serum protein fractions. Approximately $10.0 \mathrm{~mL}$ of blood samples were collected from the jugular vein into serum gel separator tubes without anticoagulant (Meus, Piove di Sacco, Italy). The serum was separated by centrifugation at $3000 \mathrm{~g}$ for 30 minutes. The harvested serum was dispensed into plastic tubes, and frozen at $-20{ }^{\circ} \mathrm{C}$ until it was analyzed.

The concentrations of total proteins (TP, g/l) were determined according to the biuret method on an automated biochemical analyzer Alizé (Lisabio, Pouilly-en-Aixois, France) using commercial diagnostic kits (Randox Laboratories Ltd., Crumlin,, United Kingdom). Zone electrophoresis on agarose gel was used to separate serum protein fractions using an automated electrophoresis system Hydrasys (Sebia Corporate, Evry Cedex, France) with commercial diagnostic kits Hydragel 7 Proteine (Sebia Corporate, Evry Cedex, France) according to the procedure described by the manufacturer. The electrophoretic gels were scanned using the densitometry scanning system Epson Perfection V700 (Epson America Inc., California, USA) by light transmission and conversion into an optical density curve. The visualization of gel images, and the identification and quantification of protein fractions were performed by computer software Phoresis version 5.50 (Sebia Corporate, Evry Cedex, France).

The protein fractions were divided into the following bands: albumin, $\alpha_{1}$ - and $\alpha_{2}$ globulins, $\beta_{1}$ - and $\beta_{2}$-globulins, and $\gamma$-globulins. Each fraction was expressed in relative concentrations $(\%)$ according to the optical density, and in absolute concentrations ( $\mathrm{g} / \mathrm{l})$ calculated from the concentrations of total serum proteins. The ratios of albumin to globulins $(\mathrm{A} / \mathrm{G})$ were calculated also.

Statistical analyses of the results were done by using the programme GraphPad Prism V5.02 (GraphPad Software Inc., California, USA). The relative and absolute concentrations of serum protein fraction in each evaluated group were expressed as arithmetic means (x) and standard deviations (SD). Kolmogorov-Smirnov Test for normality was used to determine whether sample data were normally distributed. The data passed the normality test. One-way analysis of variance (ANOVA) was applied to evaluate the effect of various diseases on the concentrations of serum protein fractions. The significance of differences in values compared to healthy animals was examined by Tukey's Multiple Comparison Test.

\section{RESULTS}

The results are presented in Tables 1 and 2. Representative examples of electrophoretic patterns of serum proteins in a clinically healthy cow and cows with various inflammatory diseases are shown in Figs. 1a-d. 
Table 1. Comparison of the relative concentrations of serum protein fractions $(\%)$ and albumin/globulin ratios $(\mathrm{A} / \mathrm{G})$ between healthy cows and cows with various inflammatory diseases (mean $\pm \mathrm{SD})$

\begin{tabular}{|c|c|c|c|c|c|c|}
\hline \multirow{2}{*}{ Variables } & & \multicolumn{4}{|c|}{ Groups of cows } & \multirow[b]{2}{*}{ P value } \\
\hline & & $\begin{array}{c}\text { Healthy } \\
(n=14)\end{array}$ & $\begin{array}{c}\text { Post-partum } \\
\text { metritis }(n=10)\end{array}$ & $\begin{array}{c}\text { Clinical } \\
\text { mastitis }(n=7)\end{array}$ & $\begin{array}{l}\text { Hoof diseases } \\
\qquad(\mathrm{n}=23)\end{array}$ & \\
\hline \multirow{2}{*}{ Albumin } & $\mathrm{x}$ & 44.9 & $36.2^{*}$ & 36.2 & $35.5^{* *}$ & \multirow{2}{*}{$<0.01$} \\
\hline & $\pm \mathrm{SD}$ & 3.8 & 10.7 & 8.3 & 7.6 & \\
\hline \multirow{2}{*}{$\alpha_{1}$-globulins } & $\mathrm{x}$ & 6.0 & $9.1^{* * *+}$ & $6.9^{+}$ & $7.5^{*}$ & \multirow{2}{*}{$<0.001$} \\
\hline & $\pm \mathrm{SD}$ & 0.7 & 2.0 & 1.9 & 1.6 & \\
\hline \multirow{2}{*}{$\alpha_{2}-$ globulins } & $\mathrm{x}$ & 12.4 & 11.4 & 10.9 & 11.8 & \multirow{2}{*}{ n.s. } \\
\hline & $\pm \mathrm{SD}$ & 0.7 & 2.1 & 1.2 & 1.6 & \\
\hline \multirow[b]{2}{*}{$\beta_{1}-$ globulins } & $\mathrm{x}$ & 7.6 & $9.7^{* *}$ & $9.8^{* *}$ & $9.1^{* *}$ & \multirow{2}{*}{$<0.001$} \\
\hline & $\pm \mathrm{SD}$ & 0.8 & 1.4 & 1.1 & 1.6 & \\
\hline \multirow{2}{*}{$\beta_{2}$ - globulins } & $\mathrm{x}$ & 6.1 & 6.7 & 7.6 & 7.4 & \multirow{2}{*}{ n.s. } \\
\hline & $\pm \mathrm{SD}$ & 1.1 & 1.6 & 1.6 & 1.8 & \\
\hline \multirow{2}{*}{$\gamma$-globulins } & $\mathrm{x}$ & 23.0 & 26.9 & 28.7 & 28.6 & \multirow[b]{2}{*}{ n.s. } \\
\hline & $\pm \mathrm{SD}$ & 2.6 & 11.1 & 5.0 & 6.1 & \\
\hline \multirow{2}{*}{$\mathrm{A} / \mathrm{G}$} & $\mathrm{x}$ & 0.83 & 0.61 & 0.59 & $0.57 * *$ & \multirow{2}{*}{$<0.001$} \\
\hline & $\pm \mathrm{SD}$ & 0.13 & 0.29 & 0.19 & 0.19 & \\
\hline
\end{tabular}

$\mathrm{P}$ value - significance of the differences in means; *superscripts in rows mean statistically significant difference compared with healthy cows $\left(*-\mathrm{P}<0.05,{ }^{* *}-\mathrm{P}<0.01,{ }^{* * *}-\mathrm{P}<0.001\right) ;{ }^{+}$superscripts in rows mean statistically significant differences between the groups of cows $(\mathrm{P}<0.05)$; n.s. - not significant

Table 2. Comparison of the concentrations of serum total proteins (TP) and protein fractions $(\mathrm{g} / \mathrm{l})$ between healthy cows and cows with various inflammatory diseases (mean $\pm \mathrm{SD}$ )

\begin{tabular}{|c|c|c|c|c|c|c|}
\hline \multirow{2}{*}{ Variables } & & \multicolumn{4}{|c|}{ Groups of cows } & \multirow[b]{2}{*}{$\mathbf{P}$ value } \\
\hline & & $\begin{array}{l}\text { Healthy } \\
(n=14)\end{array}$ & $\begin{array}{c}\text { Post-partum } \\
\text { metritis }(n=10)\end{array}$ & $\begin{array}{c}\text { Clinical } \\
\text { mastitis }(n=7)\end{array}$ & $\begin{array}{l}\text { Hoof diseases } \\
\qquad(n=23)\end{array}$ & \\
\hline \multirow{2}{*}{$\mathrm{TP}$} & $\mathrm{x}$ & 75.7 & $68.9^{+}$ & 80.1 & $80.3^{+}$ & \multirow{2}{*}{$<0.05$} \\
\hline & $\pm \mathrm{SD}$ & 3.1 & 12.4 & 3.6 & 13.0 & \\
\hline \multirow{2}{*}{ Albumin } & $\mathrm{x}$ & 34.0 & $24.1 * * *$ & 28.9 & $28.2^{*}$ & \multirow{2}{*}{$<0.001$} \\
\hline & $\pm \mathrm{SD}$ & 2.4 & 5.3 & 6.4 & 6.0 & \\
\hline \multirow{2}{*}{$\alpha_{1}-$ globulins } & $\mathrm{x}$ & 4.5 & $6.1 * *$ & 5.5 & $5.9^{* *}$ & \multirow{2}{*}{$<0.001$} \\
\hline & $\pm \mathrm{SD}$ & 0.6 & 1.1 & 1.6 & 1.0 & \\
\hline \multirow[b]{2}{*}{$\alpha_{2}-$ globulins } & $\mathrm{x}$ & 9.4 & $7.7^{*}$ & 8.7 & 9.4 & \multirow{2}{*}{$<0.05$} \\
\hline & $\pm \mathrm{SD}$ & 0.8 & 1.0 & 1.2 & 2.0 & \\
\hline \multirow{2}{*}{$\beta_{1}$ - globulins } & $\mathrm{x}$ & 5.8 & 6.6 & $7.8^{* *}$ & $7.3^{* *}$ & \multirow{2}{*}{$<0.001$} \\
\hline & $\pm \mathrm{SD}$ & 0.7 & 1.1 & 1.0 & 1.4 & \\
\hline \multirow{2}{*}{$\beta_{2}$-globulins } & $\mathrm{x}$ & 4.6 & $5.0^{+}$ & 6.1 & $5.9^{+}$ & \multirow{2}{*}{$<0.05$} \\
\hline & $\pm \mathrm{SD}$ & 0.9 & 1.6 & 1.5 & 1.7 & \\
\hline \multirow{2}{*}{$\gamma$-globulins } & $\mathrm{x}$ & 17.5 & 19.7 & 23.0 & 23.5 & \multirow[b]{2}{*}{ n.s. } \\
\hline & $\pm \mathrm{SD}$ & 2.3 & 11.8 & 4.5 & 8.2 & \\
\hline
\end{tabular}

$\mathrm{P}$ value - significance of the differences in means; $*$ superscripts in rows mean statistically significant difference compared with healthy cows $(*-\mathrm{P}<0.05$, ** $-\mathrm{P}<0.01$, *** $-\mathrm{P}<0.001)$; $^{+}$superscripts in rows mean statistically significant differences between the groups of cows $(\mathrm{P}<0.05)$; n.s. - not significant 

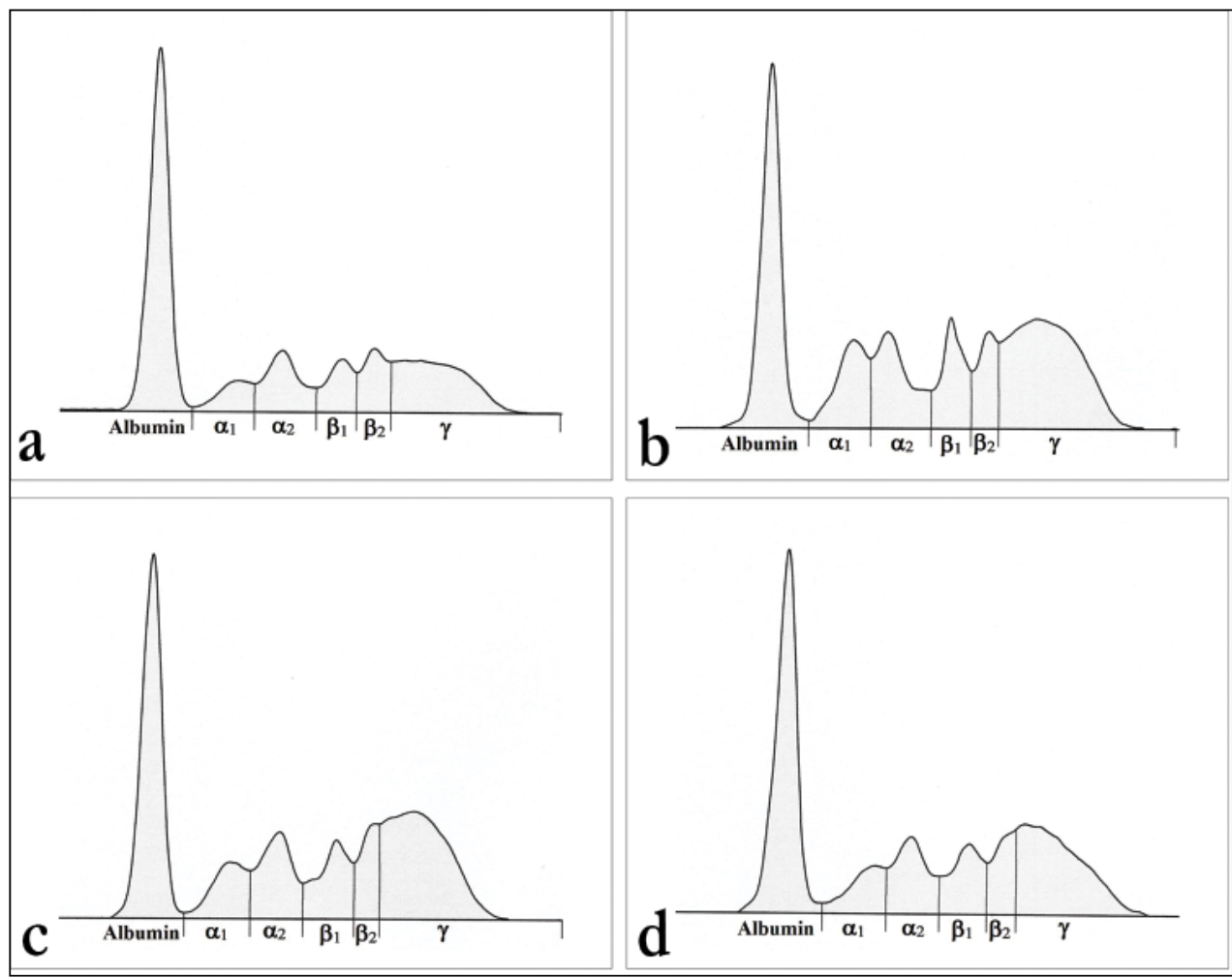

Figure 1. Representative agarose gel eletrophoretograms in a clinically healthy cow (a), cow with clinical metritis (b), mastitis (c) and dermatitis digitalis (d)

The evaluation of the relative concentrations of albumin showed significant differences between clinically healthy cows and cows affected by inflammatory diseases $(\mathrm{P}<0.01$, Table 1). The values recorded in sick cows were lower compared with healthy cows, with the lowest mean concentration in cows with hoof diseases $(\mathrm{P}<0.01)$. Significant differences between the evaluated groups of animals were found also for the relative concentrations of $\alpha_{1}$-globulins $(\mathrm{P}<0.001)$. The highest mean value among the sick cows was found in cows with metritis $(\mathrm{P}<0.001)$. On the other hand, the relative concentrations of $\alpha_{2}$-globulins in the affected animals were non-significantly lower compared with healthy ones. The relative concentrations of $\beta_{1}$-globulins showed a trend of significantly higher values in sick cows than in healthy animals $(\mathrm{P}<0.001)$, with the highest values in cows with metritis and mastitis $(\mathrm{P}<0.01)$. The relative concentrations of $\beta_{2}$-globulins were non-significantly higher in cows with inflammatory diseases. The differences observed between the groups of animals were not significant. Similarly, the relative concentrations of $\gamma$-globulins were non-significantly higher in sick cows than in healthy animals. The highest mean values were recorded in cows with mastitis and hoof diseases. An opposite trend was observed in the A/G ratios, being significantly lower in cows suffering from inflammatory diseases $(\mathrm{P}<0.001)$. The lowest mean value was found in cows with hoof diseases $(\mathrm{P}<0.01)$. 
Significant differences between the evaluated groups of cows were found for total serum protein concentrations $(\mathrm{P}<0.05$, Table 2$)$. While the mean concentration observed in cows with metritis was slightly lower compared with healthy animals, the values found in cows with mastitis and hoof diseases were higher. Highly significant differences between the cows were observed also in the absolute concentrations of albumin $(\mathrm{P}<0.001)$, with a trend of lower values in the sick cows. The lowest mean value among the affected cows was recorded in cows with metritis $(\mathrm{P}<0.001)$. An opposite trend was found in the absolute concentrations of $\alpha_{1}$-globulins, with values being higher in cows suffering from inflammatory diseases compared with healthy ones $(\mathrm{P}<0.001)$. On the other hand, the absolute concentrations of $\alpha_{2}$-globulins were lower in the affected cows, with the lowest mean value in cows with metritis $(\mathrm{P}<0.05)$. Significant differences between the evaluated groups of animals were found also for the absolute concentrations of $\beta_{1}$-globulins $(\mathrm{P}<0.001)$. The values found in sick cows were higher compared with healthy animals, with the highest mean value in cows with mastitis $(\mathrm{P}<0.01)$. Similarly, the absolute concentrations of $\beta_{2}$-globulins observed in the evaluated groups of animals were significantly different $(\mathrm{P}<0.05)$, with a trend of higher values in sick cows. The absolute concentrations of $\gamma$-globulins were nonsignificantly higher in the affected cows, with the highest mean value in cows with hoof diseases.

\section{DISCUSSION}

In human clinical practice, the main area of the application of serum protein electrophoresis is in the identification and differentiation of patients with monoand polyclonal gammopathies and other disorders of serum proteins [11]. In routine veterinary practice, protein electrophoresis is commonly used to support a clinical diagnosis of diseases characterized by dysproteinemia, or to identify the presence of inflammation with increased $\alpha$ - and $\gamma$-globulins. According to Cray and Tatum [2], electrophoresis of serum proteins may provide information on chronic or acute inflammatory processes in the animal patient, help to determine the treatment, and may be used for serial evaluation of the response to treatment. Despite the usefulness of protein electrophoresis in the evaluation of altered serum protein pattern also in farm animals, little is known about the changes occurring in serum protein fractions in cows affected by some important and frequent inflammatory diseases, including mastitis, metritis, as well as hoof diseases.

Analyses of total serum proteins showed higher values in cows suffering from mastitis and hoof diseases. Kováč et al. [12] found in cows with clinical, as well as sub-clinical mastitis higher concentrations of total proteins in serum attributed to the response of the organism to inflammation. Matei et al. [13] reported also that the increased concentrations of total serum proteins in cows with mastitis are caused predominantly by the increase of serum globulins, and indicate an activation of immune responses following infection of the mammary gland. Similarly, Jawor et al. [14] recorded higher 
total protein values in animals with limb diseases suggesting an inflammatory state. On the other hand, lower mean concentration of total proteins was found in our study in cows with post-partum metritis compared with the healthy ones. Lyubestsky [15] and Ahmad et al. [16] presented higher values of total serum proteins in endometritic cows when compared to cyclic cows probably as a result of bacterial infection. However, endotoxins released by certain bacteria may cause destruction and necrosis of the liver with various degrees of hepatic dysfunction, which may result in inhibition of protein synthesis [17].

In the concentrations of serum albumin, a trend of lower values was found in cows with mastitis, post-partum metritis, as well as hoof diseases. Several studies have observed lower serum concentrations of albumin in cows with mastitis compared with healthy cows $[18,19]$. This general decrease of albumin concentrations in sick animals may be attributed to the role of albumin as a negative acute phase protein [20]. Similarly, Burke et al. [21] and Priest et al. [22] found in cows with subclinical endometritis as measured by uterine polymorphonuclear cells lower values of albumin compared to unaffected cows. In animals with hoof diseases only slightly lower albumin concentrations were found. On the other hand, Yaylak et al. [23] recorded in cows with a lameness score of 4 significantly lower concentrations of albumin. These differences might be caused by the severity of the disease in the animals included into the studies. The relationship between the illness and blood metabolites in lame cows is not well described. According to Whitaker et al. [24], albumin together with globulin values are used to monitor inflammatory diseases, when globulin concentrations increase and albumin decreases.

The concentrations of $\alpha$-globulins were also altered by the disease in the evaluated cows. While the values of $\alpha_{1}$-globulins were higher in sick cows, the $\alpha_{2}$-globulins were unaffected or slightly lower in the diseased animals. The greatest concentrations of $\alpha_{1}$-globulins were recorded in cows with post-partum metritis. The alpha fraction is composed of a large number of individual proteins, which belong to the group of so called acute phase proteins. They have specific functions in the regulation of different stages of inflammatory processes and in the restoration of the homeostasis [20]. Alpha ${ }_{1}$-antitrypsin, $\alpha_{1}$-acid glycoprotein, $\alpha_{1}$-antichymotrypsin, $\alpha_{1}$-fetoprotein, and $\alpha_{1}$ lipoprotein migrate in the $\alpha_{1}$-globulin fraction, while haptoglobin, $\alpha_{2}$-microglobulin, $\alpha_{2}-$ macroglobulin, ceruloplasmin, $\alpha_{2}$-antiplasmin and $\alpha_{2}$-lipoprotein have been identified in the $\alpha_{2}$-globulin fraction [1]. The increases of the alpha fractions may be typically related to the increases in the concentrations of these proteins, as a result of the activation of the host inflammatory responses. Intense changes in the concentrations of many acute phase proteins were reported in dairy cows with various inflammatory diseases. Brodzki et al. [9] obtained higher concentrations of haptoglobin and serum amyloid A in the serum of cows with endometritis in the period early post partum when compared with healthy ones. Higher concentrations of $\alpha_{1}$-acid glycoprotein, haptoglobin and ceruloplasmin were found also by Sheldon et al. [25] in cows with uterine bacterial contamination. Similarly, many studies showed an increased production of major acute phase proteins, haptoglobin and serum amyloid $\mathrm{A}$, in serum and milk of 
dairy cows with mastitis $[26,27]$. Higher concentrations of some acute phase proteins have been found also in lame cows by Kujala et al. [28] and Smith et al. [8]. However, there are very scarce literature data about the changes in globulin fractions in cows affected by the aforementioned diseases. The only study dealing with the evaluation of changes in the concentrations of protein fractions in the monitoring and treatment of limb diseases in dairy cows was presented by Jawor et al. [14]. They found considerably higher values of $\alpha$-globulins in the affected animals suggesting a serious inflammatory state. Similarly, our study showed higher concentrations of $\alpha_{1}$-globulins in cows with hoof diseases, but the values of $\alpha_{2}$-globulins were less affected by the disease. These differences in the electrophoretic pattern of $\alpha$-globulins in cows affected by various inflammatory diseases might be caused by the differences in the reactivity of acute phase proteins from these fractions to impaired homeostasis. Different disease severity in the evaluated animals might be another reason for the variations observed in the electrophoretic mobility of $\alpha$-globulins (more severe diseases are accompanied by stronger acute phase response) [29].

The $\beta$-globulin fractions include some other important proteins, including complement, transferrin, $\beta_{2}$-microglobulin, as well as C-reactive protein. These proteins are involved in the inflammatory and stress responses and, thus, may be responsible for higher concentrations of $\beta$-globulins in cows affected by inflammatory diseases [30]. Lactoferrin belongs also into this group of globular proteins. It is present in the colostrum and milk of most mammals, but can be found also in external secretions such as saliva, bile, sperm or cervical mucus. During the inflammatory reactions, lactoferrin is liberated into the extracellular medium from secondary granules of the neutrophils and it is possible to determine its concentrations in various biological fluids, including blood serum [31]. According to Kanyshkova et al. [32], the concentrations of lactoferrin in the blood increase during infections and most inflammatory reactions, which might affected the concentrations of $\beta$-globulins in the diseased cows evaluated in our study. Moreover, in response to different antigenic stimulation, some immunoglobulins (mainly $\operatorname{IgM}$ or $\operatorname{IgA}$ ) may migrate into the $\beta$ region or $\beta-\gamma$ interzone and produce a beta-gamma fusion with no clear demarcation between these fractions [33]. This phenomenon was observable in our study in thirteen cows with hoof diseases and in one cow suffering from clinical mastitis. Evans and Duncan [34] stated that the pattern of $\beta-\gamma$ bridging is pathognomic for chronic liver diseases or hepatic cirrhosis. However, Camus et al. [35] reported that $\beta-\gamma$ bridging does not have a strong predictive value for hepatic diseases in dogs, cats, or horses, and may be frequently found in association with various infectious diseases. Our results showed that severe hoof diseases may be also accompanied by $\beta-\gamma$ fusion. However, further studies would be helpful to better describe this pattern in animals suffering from inflammatory diseases.

The predominant part of immunoglobulins of various classes migrates into the $\gamma$-fraction. Increases of the $\gamma$-globulin production are very frequent and may be found in many pathological conditions, mainly chronic inflammatory processes and severe infections [1]. Higher (although nonsignificantly) concentrations of $\gamma$-globulins 
were found in our study in cows affected by inflammatory diseases, with the highest values in cows with mastitis and hoof diseases. Korhonen et al. [36] reported that the concentrations of immunoglobulins in the blood serum of cows increase with the increase of udder infections, especially during acute infections. In cows with latent and sub-clinical udder inflammation, the immunoglobulin values increased only insignificantly in comparison with healthy cows. This non-significant increase of immunoglobulins observed also in our study may be caused by the intensification of immigration of $\mathrm{IgG}$ and $\mathrm{IgM}$ from the blood circulation into the udder tissue in order to protect the udder from further manifestation of infection [37]. In the cows with post-partum metritis, only a slight increase of $\gamma$-globulin concentrations was found in this study.

The shifts in the concentrations of albumin and globulins lead also to changes in the $\mathrm{A} / \mathrm{G}$ ratio. The values recorded in sick animals were significantly lower, with the lowest value in cows affected by hoof diseases. Many disease conditions may alter the relative concentrations of albumin and globulins, changing their proportion. The decreased A/ $G$ ratios observed in our study in cows with inflammatory diseases may be related to the overproduction of globulins, caused by the disease. According to Alberghina et al. [38], the interpretation of $\mathrm{A} / \mathrm{G}$ ratio is very important itself providing information about the changes in electrophoretic pattern, and could help in the classification and identification of dysproteinemias.

From the results of this study we can conclude that some inflammatory diseases of dairy cows may cause different alterations in the electrophoretic pattern of serum proteins. Post-partum metritis was associated with significantly lower concentrations of albumin and significantly higher values of $\alpha_{1}$-globulins compared with clinically healthy cows. The cows with clinical mastitis showed higher $\beta_{1}$ - and $\gamma$-globulin fractions, while in cows affected by hoof diseases we found significantly lower concentrations of albumin and higher values of $\alpha_{1^{-}}, \beta_{1}^{-}, \beta_{2}^{-}$, as well as $\gamma$-globulins. Moreover, the serum protein electrophoretic pattern of more than half of the group of cows with hoof diseases showed $\beta-\gamma$ bridging. However, the establishment of the diagnostic significance and accuracy of the serum protein electrophoresis in the bovine clinical practice needs further investigations.

\section{Acknowledgements}

This work was supported by Scientific Grant Agency of Ministry of Education SR No. $1 / 0486 / 17$ and 1/0154/15.

\section{Authors' contributions}

TC, MP and NO conceived of the study, and participated in its design and coordination and helped to draft the manuscript. TC carried out the immunoassays. NO participated 
in the design of the study and performed the statistical analysis. All authors read and approved the final manuscript.

\section{Declaration of conflicting interests}

The author(s) declared no potential conflicts of interest with respect to the research, authorship, and/or publication of this article.

\section{REFERENCES}

1. O’Connell TX, Horite TJ, Kasravi B: Understanding and interpreting serum protein electrophoresis. Am Fam Physician 2005, 71:105-112.

2. Cray C, Tatum LM: Applications of protein electrophoresis in avian diagnostics. J Avian Med Surg 1998, 12:4-10.

3. Abate $\mathrm{O}$, Zanatta R, Malisano T, Dotta U: Canine serum protein patterns using highresolution electrophoresis (HRE). Vet J 2000, 159:154-160.

4. Gerou-Ferriani M, McBrearty AR, Burchmore RJ, Jayawardena KGI, Eckersall PD, Morris JS: Agarose gel serum protein electrophoresis in cats with and without lymphoma and preliminary results of tandem mass fingerprinting analysis. Vet Clin Pathol 2011, 40:159173.

5. Tappin SW, Taylor SS, Tasker S, Dodkin SJ, Papasouliotis K, Murphy KF: Serum protein electrophoresis in 147 dogs. Vet Rec 2011, 168:456.

6. Warnick LD, Janssen D, Guard CL, Grohn YT: The effect of lameness on milk production in dairy cows. J Dairy Sci 2001, 84:1988-1997.

7. Lee JI, Kim IH: Pregnancy loss in dairy cows: the contributing factors, the effect on reproductive performance and the economic impact. J Vet Sci 2007, 8:283-288.

8. Smith BI, Kauffold J, Sherman L: Serum haptoglobin concentrations in dairy cattle with lameness due to claw disorders. Vet J 2010, 186:162-165.

9. Brodzki P, Kostro K, Brodzki A, Wawron W, Marczuk J, Kurek L: Inflammatory cytokines and acute-phase proteins concentrations in the peripheral blood and uterus of cows that developed endometritis during early postpartum. Theriogenology 2015, 84:11-18.

10. Jackson PGG, Cockcroft PD: Clinical examination of farm animals. Blackwell Science Ltd., Blackwell Publishing Company, Oxford, United Kingdom, 2002, 166 pp.

11. Vavricka SR, Burri E, Beglinger C, Degen L, Manz M: Serum protein electrophoresis: An underused but very useful test. Digestion 2009, 79:203-210.

12. Kováč G, Tóthová C, Nagy O, Seidel H: Milk amyloid A and selected serum proteins in cows suffering from mastitis. Acta Vet Brno 2011, 80:3-9.

13. Matei ST, Groza L, Andrei S, Bogdan L, Ciupe S, Petrean A: Serum metabolic parameters in healthy and subclinical mastitis cows. Bull Univ Agricult Sci Vet 2010, 67:110.

14. Jawor P, Steiner S, Stefaniak T, Baumgartner W, Rzasa A: Determination of selected acute phase proteins during the treatment of limb diseases in dairy cows. Vet Med 2008, 53:173183. 
15. Lyubestsky VI: Plasma protein fractions in cows with post parturient endometritis. VisnikAgrarnoi-Nauli 1997, 6:28-33.

16. Ahmad I, Lodhi LA, Qureshi ZI, Younis M: Studies on blood glucose, total proteins, urea and cholesterol levels in cyclic, non-cyclic and endometritic crossbred cows. Pakistan Vet J 2004, 24:92-94.

17. Semacan A, Sevinc M: Liver function in cows with retained placenta. Turk J Vet Anim Sci 2005, 29:775-778.

18. Katholm J, Andersen PH, Haubro-Andersen P: Acute coliform mastitis in dairy cows: Endotoxin and biochemical changes in plasma and colony-forming units in milk. Vet Rec 1992, 131:513-514.

19. Rişvanli A, Türköz Y, Kalkan C, Çetin H: An investigation on the serum levels of biochemical variables in the cows with clinical mastitis. Firat Üniv Sağlik Bil Derg 1999, 13:131-134.

20. Gruys E, Obwolo MJ, Toussaint MJM: Diagnostic significance of the major acute phase proteins in veterinary clinical chemistry: a review. Vet Bull 1994, 64:1009-1018.

21. Burke CR, Meier S, McDougall S, Compton C, Mitchell M, Roche JR: Relationships between endometritis and metabolic state during the transition period in pasture-grazed dairy cows. J Dairy Sci 2010, 93:5363-5373.

22. Priest NV, McDougall S, Burke CR, Roche R, Mitchell M, McLeod KL, Greenwood SL, Meier S: The responsiveness of subclinical endometritis to a nonsteroidal anti-inflammatory drug in pasture-grazed dairy cows. J Dairy Sci 2013, 96:4323-4332.

23. Yaylak E, Yenisey Ç, Seyrek K: Effect of lameness, stage of lactation and body condition score on some blood parameters in Holstein cows. Asian J Anim Vet Adv 2009, 4:245-251.

24. Whitaker DA, Goodger WJ, Garcia M, Perera BMAO, Wittwer F: Use of metabolic profiles in dairy cattle in tropical and subtropical countries on smallholder dairy farms. Prev Vet Med 1999, 38:119-131.

25. Sheldon IM, Noakes DE, Rycroft A, Dobson H: Acute phase protein responses to uterine bacterial contamination in cattle after calving. Vet Rec 2001, 148:172-175.

26. Eckersall PD, Young FJ, McComb C, Hogarth CJ, Safi S, Weber A, McDonald T, Nolan AM, Fitzpatrick JL: Acute phase proteins in serum and milk from dairy cows with clinical mastitis. Vet Rec 2001, 148:35-41.

27. Grönlund U, Hultén C, Eckersall PD, Hogarth C, Persson Waller K: Haptoglobin and serum amyloid $\mathrm{A}$ in milk and serum during acute and chronic experimentally induced Staphylococcus aureus mastitis. J Dairy Res 2003, 70:379-386.

28. Kujala M, Orro T, Soveri T: Serum acute phase proteins as a marker of inflammation in dairy cattle with hoof diseases. Vet Rec 2010, 166:240-241.

29. Young CR, Wittum TE, Stanker LH, Perio LJ, Griffin DD, Littledike T: Serum haptoglobin concentrations in a population of feedlot cattle. Am J Vet Res 1996, 57:138-141.

30. Bernabucci U, Lacetera N, Danieli PP, Bani P: Influence of different periods of exposure to hot environment on rumen function and diet digestibility in sheep. Int J Biometeorol 2009, 53:387-395.

31. Iyer S, Lonnerdal B: Lactoferrin, lactoferrin receptors and iron metabolism. Eur J Clin Nutr 1993, 47:232-241.

32. Kanyshkova TG, Buneva VN, Nevinsky GA: Lactoferrin and its biological functions. Biochemistry (Moscow) 2001, 66:1-7. 
33. Morris D, Johnston JK: Alterations in blood proteins. In: Smith BP (ed.): Large animal internal medicine. 3rd ed., Mosby, St. Louis, 2002, 426-433.

34. Evans EW, Duncan JR: Proteins, lipids, and carbohydrates. In: Latimer KW, Mahaffey EA, Prasse KW (eds.): Duncan \& Prasse's Veterinary Laboratory Medicine Clinical Pathology. 4th ed., Blackwell Publishing, Ames, 2003, 162-192.

35. Camus MS, Krimer PM, LeRoy BE, Almy FS: Evaluation of the positive predictive value of serum protein electrophoresis beta-gamma bridging for hepatic disease in three domestic animal species. Vet Pathol 2010, 47:1064-1070.

36. Korhonen H, Marnila P, Gill HS: Milk immunoglobulins and complement factors. Br J Nutr 2000, 84:75-80.

37. Kociņa I, Antāne V, Lūsis I: The concentration of immunoglobulins A, G, and M in cow milk and blood in relation with cow seasonal keeping and pathogens presence in the udder. Proc Latv Univ Agr 2012, 27:44-53.

38. Alberghina D, Giannetto C, Vazzana I, Ferrantelli V, Piccione G: Reference intervals for total protein concentration, serum protein fractions, and albumin/globulin ratios in clinically healthy dairy cows. J Vet Diagn Invest 2011, 23:111-114.

\title{
ELEKTROFORETSKI PROFIL SERUMSKIH PROTEINA KOD MLEČNIH KRAVA SA ZAPALJENSKIM REAKCIJAMA
}

\author{
TÓTHOVÁ Csilla, MUDROŇ Pavol, NAGY Oskar
}

Cilj studije je bio da se ispita elektroforetski profil serumskih proteina kod mlečnih krava koje su imale inflamatorne reakcije i različita oboljenja, kao i da se ispita uticaj ovih oboljenja na koncentracije pojedinih frakcija proteina. U ogledu je bilo 40 krava (holštajn-frizijska rasa, slovačko šareno goveče kao i melezi) koje su imale zapaljenske reakcije različite etiologije, uključujući postpartalni metritis (10 životinja), mastitis (7) i obolenja papaka (23). Starost životinja je bila od 3,5 do 8 godina. Četrnaest klinički zdravih krava je bilo u okviru kontrolne grupe. Kravama su uzimani uzorci krvi u cilju određivanja ukupnih serumskih proteina kao i frakcija proteina seruma. Frakcije proteina su podeljene u albumine $\alpha 1-, \alpha 2-, \beta 1-, \beta 2$ - i $\gamma$-globuline. Kod krava koje su imale post-partalni metritis, uočeno je značajno smanjenje koncentracije albumina $(\mathrm{P}<0,001)$ kao i značajno povećanje $\alpha 1$-globulina $(\mathrm{P}<0,01)$ u poređenju sa kontrolnim životinjama. Značajno veća koncentracija $\beta 1$-globulina $(\mathrm{P}<0,001)$ uočena je kod krava sa mastitisom pri čemu $\gamma$-globulinska frakcija nije bila značajno povećana. Kod životinja koje su imale zapaljensku reakciju na papcima, uočene su značajno manje koncentracije albumina $(\mathrm{P}<0,001)$, značajno veće koncentracije $\alpha 1$ - and $\beta 1$-globulina $(\mathrm{P}<0,001)$ uz povećanje $\beta 2$ - and $\gamma$-globulinskih frakcija koje nije bilo značajno. Ispitujući elektroforetski profil serumskih proteina kod 13 životinja sa zapaljenskom reakcijom na papcima, uočena je povezanost $\beta-\gamma$ frakcija. Rezultati koji su dobijeni, ukazuju na naglašen uticaj zapaljenskih reakcija na koncentracije pojedinih frakcija 
serumskih proteina kod mlečnih krava. Međutim, neophodna su dalja ispitivanja u cilju utvrđivanja značaja elektroforetskog profila serumskih proteina kao dijagnostičkog nalaza u kliničkoj praksi, a u odnosu na zapaljenske reakcije kod mlečnih krava. 